\title{
ETHNIC TOLERANCE FORMATION OF STUDENTS ON THE PRINCIPLES OF MULTICULTURALISM
}

\author{
Zhang Xiaoxing \\ Postgraduate student \\ National Pedagogical Dragomanov University, Ukraine \\ 527560292@qq.com \\ ORCID ID 0000-0003-2183-500X
}

\section{ABSTRACT}

The paper presents a theoretical and methodological substantiation processes connections of multicultural education and the formation of ethnic tolerance of students. Historical and pedagogical analysis of the formation of positive emotional and value attitude to people of othernationalities have been done. The principle of multiculturalism is defined as a pedagogical standard of human involvement to an ethnic, national and world cultures, forming readiness to live in a multiethnic environment.

In the article the role of tolerance of the individual regulation of relations in today's multicultural society is highlighted. Social transformation processes are characterized which actualize search methods of formation of ethnic tolerance in a multicultural area of the country. Ethnic tolerance is described as psychosocial quality of the individual that is ready for cooperation, partnership, cultural interchange, which is based on the principles of mutual understanding and patience. Pedagogical conditions and principles of ethnic tolerance of students on the basis of multiculturalism in social and educational activities of the university.

Keywords: education of ethnic tolerance; ethnic tolerance formation of students; ethnic tolerance; multiculturalism; multicultural education; tolerance.

\section{INTRODUCTION}

Ukraine's desire to join the European Union, strengthening the processes of migration, professionals' mobility improve processes, aggravated intercultural issues and tolerant attitude to other (cultures, traditions, religious beliefs), understanding their origins and preserve the traditions of each nation. These problems are exacerbated in the case of student youth, which is a national intellectual and cultural resources.

Therefore, educational institutions should act as coordinators of the transfer the younger generation of social and cultural experience of mankind, human and national cultural values. Modern high school is responsible for the preparation of young people for life in a multicultural multiethnic environment to communicate and cooperate with people of different nationalities, races, religions. As V. G. Flint emphasizes "education in XX century is not only providing knowledge and education of the individual. Education in the age of globalization and high technology is a factor of social stability and economic prosperity of the country and its competitiveness, "and therefore" it is necessary to approach it as a national strategically important issue."

The importance of the objectives of the formation of ethnic tolerance in the youth is traced in modern concepts of education and education of Ukraine, which 
emphasize the need to examine each person the national culture of the peoples living in Ukraine and world culture. In particular, the provisions contained in the National Doctrine of Education, determine the significance of "the preservation and enrichment of cultural and historical traditions, nurturing respect for national shrines, Ukrainian language and the history and culture of indigenous peoples and national minorities living in Ukraine formation of ethnic culture and interpersonal relations."

However, historical sprouts of education ethnic tolerance are inherited in the history of education much earlier in the works of thinkers of different times, including writers, philosophers, teachers, social workers, Plato, Socrates, F. Aquinas, Voltaire, Kant, Hegel, G., M. Gandhi , M. L. King; known Ukrainian educators G. S. Scovoroda, K. D. Ushinsky, S. F. Rusova and others.

The problems of co-existence and interaction of national cultures from the standpoint of human values attracted the attention H. Vashchenko, V. Vynnychenko, B. Grinchenko, M. Dragomanov, King James Version, K. Ushynsky. In particular, H. Vahschenko noted that the more people will have opportunity to develop their national culture, the more diverse and richer will be universal culture. Relying on advanced knowledge of essential features of the spiritual life of many peoples - one of the fundamental principles K. Ushynsky system. The writings of K. D. Ushynsky we find the idea that educational activities at an early stage should be based on national ideals, and then transformed into the ideal of universal plan.

Of particular importance to the formation of emotional and value attitude to people of other nationalities V. Sukhomlynsky, who felt a sense of friendship among peoples one of the noblest movements of human soul.

According to S. F. Rusova, national cultural consciousness of people is a means of ethnic unity and common value systems. Multicultural education, therefore, does not provide education rootless cosmopolitan, and should be aimed at the formation of personality, capable of harmonious coexistence in a multicultural society.

The fulfilled analysis of scientific sources of Ukrainian pedagogy allowed to testify in educational theory and practice of formation of ethnic tolerance of the individual on the basis of culture was presented in different contexts, defining the essence of the field of culture as an educational principle (M. Denysenko, G. Elizarova I. Makarenko, Sysoieva, L. Chalyapin and others) establish the role of multicultural approach to education (O. Kovalchuk) and education (I. Loshchenova, G. Rozlutska, I. Alyeksashenkova, V. Dolzhenko, V. Eremin, A. Shcheglova etc.), determining the educational prerequisites for training teachers to work in multi-ethnic space (A. Dubasenyuk) identifying features of formation of ethnic tolerance in students (Y. Huletska, L. Danilova, I. Sokolova, O. Schehlova and others).

However, in modern pedagogical studies are not fully substantiated communication processes of multicultural education and the formation of ethnic tolerance of students. Therefore, the purpose of this article is to identify pedagogical conditions and principles of ethnic tolerance of students based on the field of culture in social and educational activities of the university.

\section{MAIN CONTENT}

The basis of modern multicultural paradigm charged, philosophical ideas about the importance of preserving the uniqueness of each culture, the need 
for exchange of cultural achievements as a condition of nations for the good of man as the ultimate test of morality (S. Averintsev, M. Bahtin, Y. Lotman, A. Ohanov E. Teylor, I. Hanheldiyeva and others). The idea of cultural anthropology of many cultures; the concept of interactive communication of different cultures (M. Bahtin, V. Bibler, T. Bohatyryova, I. Vasylenko, V. Shalin, Y. Yakovets, R. Yanovsky and others). The ideas of humanistic psychology of the human need for self-actualization (A. Maslow, D. Rodzhers); perception of the concept of ethnic identity in interethnic interaction; the idea of cultural-historical psychology of the leading role of socio-cultural environment in the formation and development of personality, interconnection between a personality's culture and morality, culture and education (Bakhtin, G. Ball, W. Bibler, E. Ivanov and others).

Education should promote awareness of their human roots and instill his or her respect for other cultures. Modern citizens of multiethnic states have recognized democratic values such as fairness and equality become the protection and strengthening of all ethnic, racial, linguistic and religious groups that make up their nation country. To this end, the Council of Europe defines competence related to human life in a multicultural society. In order to control the expression (revival resurgence) of racism and xenophobia and the climate of intolerance, education should "equip" young Europeans with intercultural competence such as the perception of differences, respect for others and the ability to live with people of other cultures, languages and religions. At the same time, the formation of ethnic tolerance of the young citizen of Ukraine must not deny the national, because together they are regarded as organic components of a single process that provides a deeper understanding of both national and panhuman cultural values.

Defining the role of the individual in society, even singing live representatives of different ethnic groups and O. Pometun, L. Sultanova note that the transformation processes in society than ever actualize search for moral and spiritual grounds for conflict-free coexistence and interaction of people in the multicultural space as a social formation characterized by multi-ethnicity, speaking different languages, diversity of beliefs, traditions, ways of thinking and living. However, the positive recognition of the value and significance of differences does not preclude discussion about what sustainability can provide a multicultural world, to ensure its long-term development, security of life and human rights. Debatable is also the issue of principles in society, which would provide the dialogue of cultures and tolerance of the "other."

Determining where the individual in contemporary socio-cultural situation of ethnic tolerance problem, the researchers noticed that the young man is in the late crop interaction which requires a dialogue, tolerance, understanding and respect for the cultural identity of others. A monocultural approach is opposed to multicultural approach today. However, the optimal educational strategy builds tolerance when combined in the educational process monocultural principles and multiculturalism. On the one hand, a person must be aware of his roots, the other respect other cultures.

O. I. Pometun and L. Y. Sultanov define multiculturalism as a person's ability to integrate in your mind different cultural layers. A constant "communicationaction" person becomes a true subject of cultural-historical and educational space. The researchers emphasize that today multiculturalism is the most important aspect of implementing democracy in individual countries and in the world at large. Respect for diversity, tolerance, dialogue and cooperation under conditions of trust and mutual understanding is the best guarantee of peace and international security. This 
source of exchange, innovation, creativity, and peaceful coexistence, which should be considered, to support and promote at the international, national and local level.

So multiculturalism in modern scientific research is treated as a pedagogical principle. In summary, the principle of multiculturalism is seen by scientists as a pedagogical standard person to attract ethnic, national and world cultures, forming readiness to live in a multicultural environment. This principle requires it to take into account in the process of dialectical basic cultural property as "unity in its diversity": globality and locality, the rational and irrational, past and future, versatility and originality, the general and professional alike. This approach to the definition of multiculturalism as a leading principle in the formation of ethnic tolerance of the individual became the base for our further research work.

Under education, carried out on the basis of the principle of multiculturalism, we will determine as multicultural education. In modern psychological and pedagogical studies multicultural education is treated as a form of education that aims at mastering cultural and educational values of other cultures through knowledge of their ethnic and cultural groups, as well as the interaction of cultures on principles of mutual understanding, tolerance, dialogue and pluralism as a means of confrontation discrimination, racism and chauvinism.

The basic methodological approaches of multicultural education are:

- socio-cultural (understanding the process of socialization, assistance in adapting to a different culture and society);

- language (competence in other languages, studying and analyzing theories and levels of competence in another language);

- cognitive (understanding of the cognitive activity of students the ability to adapt the content of educational material with the requirements of multiculturalism);

- $\quad$ axiological (recognition of cultural values of their country and the people of the world).

Now to the social and educational fields, the goal of active and purposeful education appropriate mental qualities of man and society. Education for ethnic tolerance, tolerance in human relations is the most important task of education.

Tolerance enables knowledge cultures of different peoples, thus creating the preconditions of mutual understanding and respect, the position of co-operation that is key to ethnic social stability. The basis of modern educational space should be the education of tolerance, which involves changing the system of human relations, building them on mutual respect.

Among the priority tasks of the reform of the educational process for this type of problem, the researchers determined: the implementation of the principles of morality, forming awareness of the relationship of freedom, human rights and civic responsibility, interpersonal skills and prepare young people for life in a multicultural space.

A researcher of multicultural education issues, N. E. Myropolska calls such indicators breeding ethnic tolerance of the individual; the cognitive level: learning models and values of national and world culture, cultural, historical and social experience of different countries and peoples; in value-motivational level: the formation of social and statutory value-orientation and propensity to intercultural communication and exchange, and the development of empathy in relation to other countries and peoples, cultures and social groups; on action-behavioral level, active social interaction with different cultures while preserving their cultural identity. 
The problem of tolerance of youth in the multicultural environment is studied in details by O. Gryva. The author developed a model of education tolerant person and socio-pedagogical conditions of training of specialists to work in multiculturalism. Determined that to uphold the principles of democracy, protection of all citizens regardless of national, religious, ethnic or linguistic features necessary to create conditions for crystallization of ethnic tolerance. This situation should be viewed as demand sometimes forced move Ukraine towards a qualitative transformation in public policy and the establishment of new standards (Gryva O. A., 2005).

However, as noted by T. Danko particular attention to young people, nurturing their sense of tolerance that justified the rejection of divergence and desire to promote ethnic synthesis, which in turn is based on the ability to accept constructive achievements of other cultures. Together, this will help to enrich their culture, gain new opportunities for cooperation and future development in harmony and peaceful coexistence (Danko T., 2008).

An analysis of scientific sources underscores the importance of the need and necessity of conscious self-focused education and tolerance, which will be set to the individual humanist values of freedom, human rights, and assert itself to be a high quality bearer of civilization and culture.

Exploring the role of tolerance in the regulation of relations in today's multicultural society, S. Drozhzhina provides the following features that they will contribute to the peaceful resolution of ethnic conflicts: the search for compromises, civic spirit, patriotism, respect for others, respect for the rights of others, personal responsibility (before family, community members, government), wide world. In our view, these indicators should be the basis for ethnic tolerance education of young people (Drozhzhina S., 2006).

To our mind, it is appropriate to draw attention to the approach of Russian exploration Bezyulyevoy G. and G. Shelamovoy that serves not only the understanding of tolerance that is a consonant dialogue, cooperation, mutual understanding and technology and gradual development of tolerance with teachers and students from the psychological climate in the team to educational institutions, evaluation of psycho-pedagogical competence through information on the issue of tolerance and improve communication skills teacher for individual development tolerant teacher quality based on reflection and self-diagnostic difficulties in the relationship of "I" and "other." The paper notes that the absence of development of a teacher's tolerance is impossible in ensuring the development of a student's tolerance (Bezyuleva G. V., 2003).

Ethnic tolerance, according to Angelina E. O., is ensured by such factors as: willingness to cooperate and mutually beneficial partnership based on common values; commitment to cultural interchange and enrichment; capacity for mutual empathy; neutralization of complexes in negative behavior, without humiliation of his personal and social dignity; mutually respected dialogue establishment to achieve better understanding. In the works of E. Angelina pedagogical conditions of formation of ethnic tolerance among young people in multicultural educational space are determined as following: the organization of educational activities of students; construction of active interaction between teachers and students in the educational process to successfully develop a tolerant relationship; involve students in social work, which involves active participation in intensive interaction with different actors; formation of readiness of students to tolerant relations; 
age-specificity of tolerance; creating a tolerant climate in the educational process of the university; training specialists tolerance (Ethnic tolerance [Electronic resource]).

Therefore, we determined that the basis of tolerance laid in personality development are such aspects as a young man's willingness to coexistence, interaction with other people, communities, circumstances and adopting them as they are.

This allows us to continue proceeding from understanding of tolerance as respect, acceptance and proper understanding of a rich diversity of our world cultures, forms of expression and ways of being human individuality, which promote knowledge, openness, communication and freedom of thought, conscience and belief.

Human values necessary for ethnic tolerance are the ability of representatives of various ethnic cultures and mentalities to find common ground for cooperation and ways to cooperate. In solving ethnic and cultural conflicts young people are the most sensitive element of our society. In the nearest future they will be basic component of our nation, ethnic group, and the driving force of a nation. In formation of a mature personality it is important to prevent intolerance and contribute to the upbringing of manifestations of the ethnic tolerance in a culture.

\section{CONCLUSIONS}

Thus, in the content of this article ethnic tolerance is defined as a kind of tolerance, based on the principles of mutual understanding, solidarity and patience; psychosocial quality of an individual that is ready for cooperation, partnership, cultural interchange, respect personal dignity and social representatives of other ethnic groups.

The most effective way to formation of the younger generation is its ethnic tolerance education. Education for ethnic tolerance as we consider the process of preventing and overcoming manifestations of intolerance in relation to the representatives of other nations or people, formation of readiness of the individual to contact and further interaction with people of different national, ethnic or religious affiliation.

However, ethnic tolerance education of students is treated as the process of prevention and combating manifestations of intolerance in relation to members of other nations or people forming cognitive, motivational value and operational readiness of students to interact with people of different national, ethnic or religious affiliation on the basis of tolerance. Teaching students ethnic tolerance serves as the harmonization of social and educational environment of the university, creating significant personal and socio-cultural situations and ethical development of students.

Theoretical and methodological analysis of the study allowed us to determine the hypothetical pedagogical conditions of formation of ethnic tolerance of students in social and educational work of higher education:

- $\quad$ specific college age in the formation of ethnic tolerance;

- $\quad$ formation of readiness of students for personal interaction with members of other ethnic groups on the basis of tolerance;

- $\quad$ attracting students to form clubs of socio-educational activities, providing for joint creative collaboration with various entities of ethnic interaction; 
- $\quad$ using music as a means of emotional impact on the formation of ethnic tolerance of students.

\section{REFERENCES}

1. Angelina, E. Ethnic tolerance. Retrieved from http://mdu.edu.ua/spaw2/ uploads/files/4_22.pdf

2. Bezyuleva, G. (2003). Tolerance: opinion, search, decision. Moscow: Verbum-M.

3. Gryva, O. (2005). Socio-pedagogical bases of forming tolerance in children and youth in the multicultural environment: Monograph. Kyiv: PARAPAN.

4. Gukalenko, O. (2004). National school in multicultural education space. Multicultural education and national School: Materials of the "round table" of the "Pedagogika" scientific-methodical journal. Simferopol, 18-19, 36.

5. Danko, T. (2008). Social and cultural origins of extremism. Right extremism and tolerance: from the experience of Ukraine and Germany. Kyiv: Zapovit.

6. Drozhzhina, S. (2006). Tolerance as an effective factor of democratization of Ukrainian society. Multiversum. Philosophic Almanac. Kyiv: Center of spiritual culture. Retrieved from www.filosof.com.ua/Jornel/M_55/Drozhzhina.htm

7. Kremen, V. (ed.). Encyclopedia of Education. Kyiv: Yurinkom Inter.

8. Kremen, V. (2010). Philosophy of humanocentrism in educational space. Kyiv: Partnership "Znannya Ukrayiny”.

9. Pometun, A., Sultanov, L. (2010). Human in a multicultural society: study guide for higher schools teachers of elective courses for students of socio-humanistic disciplines. Kyiv: "Engineering".

10. National Doctrine for Development of Education (2002) Education of Ukraine, 33, 4.

11. Balabanova, K., Sysoyeva, S., Sokolova, I. The problems of multiculturalism in continuous professional education: scientific edition. Mariupol: MESYuS. Mariupol state university. 